\title{
IMPERFECT INFORMATION, CREDIT MARKETS AND UNEMPLOYMENT
}

\author{
Bruce C. GREENWALD \\ Bell Communications Research, Morristown, NJ 07960, USA \\ Joseph E. STIGLITZ \\ Princeton University, Princeton, NJ 08544, USA
}

\section{Introduction}

This paper attempts to describe the impact of informational imperfections in capital markets on the level and nature of unemployment. Since this task is a complicated one, two basic points should be kept in mind throughout the subsequent discussion.

First, most existing unemployment models take the existence of exogenous shocks to the marginal product of labor as a point of departure. In traditionally Keynesian models, these are 'price' shocks to the nominal marginal product of labor arising either from monetary or demand disturbances. ${ }^{1}$ In other models they are accepted without comment or explanation. ${ }^{2}$ However, given the many shortcomings of the fixed price models ${ }^{3}$ and the many equilibrating forces that ought to smooth out demand fluctuations ${ }^{4}$ some explanation for cyclical variations in the marginal product of labor is an essential part of any complete explanation of cyclical unemployment. Informational imperfections (chiefly in capital markets) provide a set of explanations for the origins, nature and apparent magnitudes of these shocks. And, since these explanations are closely related to information based

\footnotetext{
'The most familiar form of these are 'animal spirit' related shifts in the marginal efficiency of investment. But, with fixed nominal wages, any change in demand or the money supply will do as well. See Solow and Stiglitz (1968), Barrow and Grossman (1967) or Malinvaud (1977).

${ }^{2}$ See, for examples, Baily (1977) and Grossman, Hart and Maskin (1983).

${ }^{3}$ While prices and wages are fixed in nominal terms may make sense in a stable price environment it is less clear that this behavior makes sense at relatively high rates of inflation. Fixed infra-marginal prices make more sense than fixed marginal prices and marginal price and labor costs are the relevant factors in output and employment decision. Observed variations in output and employment seem to be greatest in sectors (e.g., investment goods, construction, etc.) where prices are most flexible.

${ }^{4}$ Even with fixed prices, variations in marginal costs should serve to smooth out production and investment over the business cycle. In fact, production varies more than consumption and investment varies far more than either consumption or production.
} 
explanations of the several categories of unemployment, they represent a natural starting point for the discussion.

Second unemployment is a multidimensional phenomenon involving several significant distinctions. There is to begin with an important difference between steady continuing 'unemployment' of the kind that seems to be increasingly characteristic of recent European labor markets and cyclical variations in unemployment. The latter has been the focus of traditional concern with the 'unemployment' problem. However, the former has been an cconomic phenomena of long standing and great significance. In developing economies, it has been associated with underemployment in agriculture as workers wait their turns for industrial jobs. ${ }^{5}$ In developed economies, it involves underemployment in 'secondary' sectors of the economy as workers queue up for 'primary' sector jobs. Both kinds of unemployment can be traced to informational imperfections, but the models involved, or at least the questions asked of the models, are necessarily quite different.

The next important distinction concerns differences in the nature of unemployment in the primary as opposed to secondary sectors of a developed economy. Primary sector jobs typically involve substantial jobrelated training, large potential variation in individual job performance and hence a demand for relatively high-quality workers, long-term career relationships between workers and firms and relatively high wages. Secondary sector jobs in contrast are associated with little training, high turnover and relatively low wages. Given these differences, which are presumably rooted in the technologies of the jobs in question, the determinants of both levels and variations in unemployment in the two sectors are likely to be very different. For example, training and acquisition costs are likely to be a much more important aspect of employment decisions in the primary sector than in the secondary sector. Moreover, in practice, unemployment variations appear to be different in the two sectors. ${ }^{6}$ Thus, although informational imperfections are capable of providing explanations for unemployment in both sectors, the models and factors involved will naturally differ between sectors.

In looking at cyclical unemployment, a distinction must be maintained between temporary lay-offs of workers, having a high probability of returning to their initial employers, and unemployment among workers - both new entrants and those who have been permanently displaced from their most recent jobs - who must strike entirely new wage bargains with new employers. Both phenomena require explanation (e.g., why do lay-offs not take temporary jobs with other firms? Why do the permanently displaced

\footnotetext{
${ }^{5}$ See Stiglitz (1974).

${ }^{6}$ For example, in the United States in the recessions of 1953-54, 1960-61, 1970-71 and 197576 , unemployment rates for married heads of households increased by an average of 112 percent (i.e., they slightly more than doubled) compared to an increase of only 35 percent for teenage workers and 53 percent for non-white workers.
} 
not receive and accept new, low wage offers?) and both can be explained by informational imperfections. However, as in the other cases discussed above, the different circumstances require slightly different theoretical approaches.

Finally, reductions (and increases) in the demand for labor can take on two forms: an increase in the number of workers employed or in the hours worked. A theory of unemployment must explain not only the form which unemployment takes, but also why the incidence seems to vary so greatly across groups within the population.

\section{Explanation of variations in the demand for labor}

One central function of capital markets is to distribute the risks associated with any particular enterprise among a large number of highly diversified investors. The most familiar vehicle for doing this is the sale of common stock. However, as in the case of most other insurance markets (health, life, etc.), informational imperfections (e.g., moral hazard, adverse selection) will interfere with the operation of these financial insurance mechanisms. ${ }^{?}$ For example, if a company's management with superior 'inside' information about the company's likely future prospects is willing to sell common stock to relatively less well-informed 'outside' investors at the current market price, then one obvious inference is that this market price does not undervalue and probably overvalues the company. As a result, financial markets should (and do) react to stock issue announcements by lowering the common stock prices of the companies in question. This, in turn, will inhibit the issue of equity and company managements will be forced to seek other means of insuring against the risks associated with their operations. ${ }^{8}$

Accumulation of equity over time is one means of accommodating these risks in the longer run. However, in the short run, restrictions in the level of company operations may be the only way of doing so. In the absence of complete futures markets, ${ }^{9}$ any output decision, involving as it does investments in both working and fixed capital before output is sold, is inherently a risky investment decision. Consequently changes in the economy which either increase the risks associated with a given level of output or deplete the stock

\footnotetext{
${ }^{7}$ See, for example, Arrow (1970), Wilson (1977), Rothschild and Stiglitz (1976) on insurance markets; Greenwald (1979), Stiglitz (1976) on labor markets; Jaffee and Russell (1976), Stiglitz and Weiss (1981) and Ross (1977) on financial markets, and Akerlof (1970) for a general discussion of the adverse selection issue.

${ }^{8}$ For formal models of this phenomenon see Greenwald, Stiglitz and Weiss (1984), Majluf and Myers (1984) and, in a slightly different spirit, Leland and Pyle (1977). In fact, equity issue announcements are accompanied by significant declines in stock prices of the issuing company [see Asquith and Mullins (1983)] and this is presumably related to the observation that internally generated funds are by far the predominant source of equity for most firms [sec Taggart (1983)].

${ }^{9}$ The non-existence of many futures markets may also arise from imperfect information concerning the quality and reliability of delivery on all but the simplest contracts.
} 
of firm equity capital will be accompanied by a reduction in the level of output and investment. If firms tend to hold real assets and nominal liabilities (i.e., fixed nominal debt contracts), then 'negative' money supply or demand shifts will reduce the real equity levels of firms and, in a near Keynesian way, reduce output and investment. Increased uncertainty about factor prices (e.g., 'oil shocks'), relative price variations (associated, for example, with more rapid inflation) or the direction of public policy will also reduce output. And, government interventions (e.g., in labor markets) which reduce the flexibility of firms' responses to changing market conditions will have a similar effect. ${ }^{10}$

From a labor market prospective these increases in risk, relative to equity levcls, increase the 'risk' cost associated with any increase in output and hence reduce the 'effective' or 'risk adjusted' marginal product of labor. Thus, without relying on any artificial rigidities in prices, informational imperfections in capital markets can give rise to potentially large fluctuations in the 'effective' marginal product of labor in response to changing conditions that in an economy with perfect markets would be absorbed with little or no impact on overall economic activity. Moreover an asymmetric distribution of information between borrowers and lenders may create credit rationing constraints that reinferce these basic effects (especially in response to monetary policy shifts) both as borrowers anticipate the possibility of having credit rationed in the future and as current credit constraints, by limiting working capital investments, effectively reduce the marginal product of labor. $^{11}$

\section{Lay-offs}

In the United States, at least, lay-offs from which the majority of employees return to their original employers are one of the major sources of cyclical unemployment. In the context of long-term employment relationships, variations in the 'risk' associated with variations in a firm's equity level may give rise to circumstances under which these lay-offs are an appropriate response to changing capital market conditions.

Assume for simplicity that the utility of a firm's decision-makers (whether owner-entrepreneurs or hired managers) is a function of end of period equity. Looking forward from the beginning of the period (when decisions are made), end-of-period equity is a random variable,

$$
\tilde{a}_{t}=\tilde{p}_{t} f\left(l_{t}\right)-w_{t} l_{t}+a_{t-1},
$$

\footnotetext{
${ }^{10}$ For a formal general equilibrium macroeconomic model of these phenomena see Greenwald and Stiglitz (1986).

${ }^{1}$ See Stiglitz and Weiss (1981).
} 
where

$\tilde{p}_{t} \quad$ is the uncertain end-of-period price at which the firm's output will be sold,

$l_{t}$ is the level of labor input,

$f$ is a production function of the usual sort,

$w_{t}$ is the wage paid to workers, and

$a_{t-1}$ is the beginning of period equity that the firm inherits from period $t$ -1 .

With perfect capital markets, we would have to add new equity sales to the right-hand side of eq. (1). However, as argued above, informational imperfections in capital markets will limit these sales and for simplicity we will assume that such equity sales are zero. ${ }^{12,13}$ Thus, eq. (1) implicitly embodies the informational imperfections in the capital market.

We will assume formally that in making decisions at the beginning of period $t$, a firm's decision makers

$$
\max E\left[u\left(\tilde{a}_{t}\right)\right]
$$

where the utility function $u$ is characterized by decreasing absolute risk aversion. In order to capture the constraints imposed by the existence of long-term labor contracts we will assume that the firm has an existing labor force at the beginning of period $t, I_{t}$, which is tied to the firm by the value of firm specific human capital on the one hand and the imformational and other costs of changing jobs on the other hand. Whatever wages these workers were implicitly promised in either formal or informal labor contracts at the time they were hired, the appropriate marginal cost of employing them once these contracts have been agreed to is their marginal disutility of work. We will assume that this disutility, $w_{0}$, is independent of the current marginal product of labor; being dependent on the lifetime income embodied in their long-term employment relationship (which depends, in turn, on current wages only to a limited extent). ${ }^{14}$

The first-order condition determining the optimal level of employment by

\footnotetext{
${ }^{12} \mathrm{~A}$ model having firms' managers being averse to the risk of bankruptcy but otherwise risk neutral produces results which are essentially similar to the generalized risk aversion assumed here. See Greenwald and Stiglitz (1986) which includes a justification (to the extent it is necessary) for having utility depend upon end of period equity.

${ }^{13}$ Dividends can be viewed as negative equity issues. Standard signalling arguments explain why firms may be reluctant to adjust dividends in the face of changes in economic circumstances, and why accordingly the dividend rates may, in the short run, be taken as fixed. Our model can be extended to include the endogenous determination of the dividend level; this would complicate the analysis without changing the basic conclusions.

${ }^{14}$ This is essentially the argument presented by Baily (1977), reinforced at critical points by the impact of informational imperfections.
} 
a firm facing a wage $w_{t}$ is,

$$
E\left[\tilde{u}_{t}^{\prime} \cdot\left(\tilde{p}_{t} f^{\prime}-w_{t}\right)\right]=0
$$

Rearrangement of terms and use of the fact $\left.E\left[\bar{u}_{t}^{\prime} \cdot \tilde{p}_{t}\right]=E\left[\tilde{u}_{t}^{\prime}\right] E \tilde{p}_{t}\right]+$ $\operatorname{cov}\left[\tilde{u}_{t}^{\prime}, \tilde{p}_{t}\right]$ yields the result that

$$
f^{\prime}(l)\left(1+\operatorname{cov}\left[\tilde{u}_{t}^{\prime} \cdot \tilde{p}_{t}\right]\right)=w_{t}
$$

where, by choosing suitable normalizations and units, $E\left[\tilde{u}_{t}\right]=E\left[\tilde{p}_{t}\right]=1$. On the left-hand side of eq. (3), the covariance of price levels and marginal utilities is negative as long as $u$ is characterized by aversion to risk in some degree. Thus, the impact of capital market imperfections is in general to reduce the effective marginal product of labor and consequently employment. Moreover, after a negative demand shock (or monetary disturbance) which impairs the equity base of a firm, $a_{t-1}$ will be reduced and, if $u$ is characterized by decreasing absolute risk aversion, the negative covariance term will increase in magnitude. If at the same time policy or other uncertainties increase the variance of the future price distribution, this effect will be reinforced and it may be true that

$$
f^{\prime}(\bar{l})\left(1+\operatorname{cov}\left[\tilde{u}_{t}^{\prime} \cdot \tilde{p}_{t}\right]\right)<w_{0}
$$

Under these circumstances, a firm offering long-term contracts will find it optimal to lay-off workers. The temporary nature of these lay-offs, which would ensure that the workers involved do not seek employment elsewhere, rests on the possibility that the firm will ultimately restore its equity level through the accumulation of retained earnings over time. As its equity base increases the 'risk' of increased output will decline, the effective marginal product of labor will rise and laid-off workers will be called back. ${ }^{15}$

There are several possible senses in which these temporary lay-offs represent involuntary uncmployment. Most familiarly, but perhaps least importantly, workers who look only at the average wages implied by their long-term employment relationships would be willing to work at that average wage during the period they are laid off. They may not see that the average wage is calculated to smooth out temporary variations in the marginal product of labor and is not the appropriate standard for assessing incremental employment opportunities. A second more significant sense in which these temporary lay-offs are 'involuntary' is that they represent a Pareto inefficiency. With an appropriate mechanism for spreading the risks as-

\footnotetext{
${ }^{15}$ Note that in this analysis, we have assumed complete flexibility in the (shadow) wage paid workers in the long-term contract.
} 
sociated with increased output and investment (or for circumventing credit rationing constraints), both firms and workers could profit from the employment of laid-off workers. If firms offered (and workers were willing to accept) equity shares in future output in lieu of current wages, then lay-offs could, in theory, be avoided. However, the firms willing to do this are likely to be those whose future equity values are low relative to their observable characteristics. And workers, just like outside equity investors, ought to avoid such offers. Thus, informational failures are as likely to interfere with employment contracts that distribute risk as they are with explicit financial market arrangements.

There remains the problem of why laid-off workers do not accept interim employment with other firms. If the lay-offs are recognizably temporary, then training considerations may militate against temporary employment in alternative primary jobs since alternative employers may not be able to recoup hiring and training costs in the time available. At the same lime, employment in similar jobs to those from which workers have been laid off may not be available since 'shocks' which deplete the equity stock of one firm in an industry are likely to affect other firms in a similar way. ${ }^{16}$ Finally, informational imperfections in the labor market may make it costly for workers to accept temporary jobs. First, acceptance of an alternative job (especially a low-paying secondary sector job) may be taken as evidence that the worker himself has doubts about his abilities and future prospects with his original employer. If workers are better informed about their own abilities than the labor market at large, this negative 'signal' may reduce future earnings. Second, if temporary employers observe a worker's ability and are willing to 'allow' him to return to his original employers when recalled from being laid off, this may in itself constitute a negative signal about the worker's ability. And, if at some future time, the worker seeks to leave his original employer this negative signal may reduce the value of the alternative jobs available. ${ }^{17}$

\section{Cyclical variations in hiring}

In practice, many lay-offs do not lead to re-employment and durations of unemployment appear to increase significantly in recessionary times. Wage levels in markets for unemployed workers without any rehiring expectations from their most recent employers do not, therefore, appear to adjust quickly enough to clear those markets.

\footnotetext{
${ }^{16}$ Moreover, if there are search costs, the fact that the unemployment is viewed to be temporary militates against workers expending resources to find a suitable job.

${ }^{17}$ Indeed since workers' abilities may change stochastically over time, the secondary firm's willingness to let the employee go may be a negative signal to the original employer, leading directly to lower wages.
} 
The quandry can be put in a slightly different way. Assume capital markets were perfect. Real interest rates have, historically, been low and varied little. A firm contemplating the investment of hiring a new worker asks what is the optimal time to hire him. The value of a hire at time $T$, viewed as of time 0 , is

$$
V(T)=\mathrm{e}^{-r T} \int_{T}^{S(T)}\left[b(t)-\mathrm{e}^{-r(t-T)} \mathrm{d} t,\right.
$$

where $b(t)$ is the value of the marginal product of the worker at timc $t, w(t)$ is the wage, and $S(T)$ is the termination date of a worker hired at time $T$. Differentiating with respect to $T$, we obtain

$$
V^{\prime}=r V-\mathrm{e}^{-r T}[b(T)-w(T)]+\left(\frac{\mathrm{d} S}{\mathrm{~d} T}\right)[b(S)-w(S)] \mathrm{e}^{-r S} .
$$

If $V>0$, and the period of employment is relatively long, it is clear that at the point where $V$ is maximized, $b<w$; but typically, workers are hired only after the firm has first resorted to using overtime, i.e., $b=w(1+x)$ where $x$ is the overtime premium. We thus obtain a puzzle on the timing of hiring, similar to that encountered for the timing of investment (including, in particular, investment in inventories). ${ }^{18}$

Capital market imperfections can however account for this variability in employment, when the jobs in question are primary sector jobs which involve substantial training costs and potential long-term relationships between employers and workers. Assume as before that firms maximize a function, $u$, of their end of period equity position. Assume, in addition, that an existing stock of trained workers represents the only element of each firm's capital stock. Then the value of a firm's equity at the end of period $t$ is

$$
a_{t}-y_{t}+\tilde{v}_{t},
$$

where $a_{t}$ represents the beginning of period net liquid assets of the firm, $y_{t}$ is the present value of current and committed future expenditures on the existing labor force and $\tilde{v}_{1}$ is a certainty equivalent at the end of period $t$ of the uncertain future net value from that time forward of the labor supplied by a firm's existing labor force. This last quantity is uncertain looking forward from the beginning of period $t$. Some price and productivity uncertainties will be resolved during the course of period $t$ and their

\footnotetext{
${ }^{18}$ If there is a substantial period of on-1he-job training $b(t)$ may be less than $w(t)$. However, in that case a similar contradiction arises in comparing $v^{\prime}$ at the start of a recession when hiring stops (and $v^{\prime}<0$ ) and $v^{\prime}$ at the peak of the recession when hiring recommences (i.e., $v^{\prime}=0$ ) and the firm is paying overtime.
} 
resolution is reflected in the distribution of $\tilde{v}_{t}$. The remaining uncertainties looking forward from the end of period $t$ are subsumed in the process of taking the certainty equivalent.

The first-order condition governing the hiring of an additional worker at the beginning of period $t$ is that

$$
E\left[\tilde{u}^{\prime} \cdot\left(-\frac{\mathrm{d} y_{t}}{\mathrm{~d} l_{t}}+\frac{\mathrm{d} \tilde{v}}{\mathrm{~d} l_{t}}\right)\right]=0
$$

which, using the appropriate normalization $E\left[\tilde{u}^{\prime}\right]=1$, becomes

$$
\frac{\mathrm{d} y_{t}}{\mathrm{~d} l_{t}}=E\left[\frac{\mathrm{d} \tilde{v}_{t}}{\mathrm{~d} l_{t}}\right]+\operatorname{cov}\left[\tilde{u}^{\prime}, \frac{\mathrm{d} \tilde{v}}{\mathrm{~d} l_{t}}\right]
$$

For simplicity we will assume that both the training costs borne by firms and the wages that they implicitly undertake to pay take the form of fixed payments promises at the time a worker is employed and that these have the same status as debt to the decision makers of the firm. ${ }^{19}$

If $y_{t}$ comprises total wages, then

$$
\frac{\mathrm{d} y_{t}}{\mathrm{~d} l_{t}}=\sum_{i=0}^{\infty} w_{t+i} \delta_{j}+h_{t}
$$

where $w_{t+i}$ is the wage payment promised in period $t+i, \delta_{i}$ is an adjusted discount factor encompassing the effects of both the real rate of interest and the probability that a worker quits before period $i$ (i.e., $\delta_{i}=s_{i} \bar{\delta}_{i}$ where $\bar{\delta}_{i}$ is a discount factor of the normal sort and $s_{i}$ is the probability that a worker remains with the firm through period $t+i$ ) and $h_{t}$ is the out-of-pocket cost of hiring and training a worker.

Ignoring endogenous variations in the probability of continued employment, the term $\mathrm{d} \tilde{v}_{t} / \mathrm{d} l_{t}$ is the end of period $t$ certainly equivalent of

$$
\sum_{i=0} \tilde{p}_{t+i} \cdot f^{\prime}\left(t_{t+i}\right) \delta_{t+i},
$$

\footnotetext{
${ }^{19}$ In practice, such fixed commitments make up only part of future wages with the remaining part dependent on the future productivity of workers. This could be easily accommodated within the framework outlined above by having $y_{t}$ represent only the fixed commitment portion of wages and $\tilde{v}_{t}$ be net of the contingent portion of wages. The important constraint in what follows is that the mix of fixed to contingent labor costs not be freely variable. The informational argument in support of this kind of constraint is similar to that supporting the no equity constraint. Firms that deviate from common practice by requiring that workers pay for hiring and training costs and by offering wages that are heavily weighted toward contingent payments (essentially equity in the firm) are disproportionately likely to be weak firms or firms who are prone not to fulfil contingent promises. In either case workers are presumably likely to avoid such firms.
} 
where $\tilde{p}_{t+i}$ is the future level of prices, $f^{\prime}\left(\tilde{\tau}_{t+i}\right)$ is the future marginal product of labor and, assuming firms and workers have the same discount rates, $\delta_{t+i}$ is the adjusted discount factor defined above. Assuming that $u$ is characterized by decreasing absolute risk aversion, decreases in the initial liquid equity of firms (i.e., $a_{t-1}$ ) and increases in uncertainty concerning future prices and marginal productivities will reduce the value of the certainty equivalents that make up $\mathrm{d} \tilde{v}_{t} / \mathrm{d} l_{t}$, reducing $E\left(\mathrm{~d} \tilde{v}_{t} / \mathrm{d} l_{t}\right)$. In addition as $a_{t-1}$ falls in response to negative demand or monetary shocks in period $t-1$, the magnitude of the $\operatorname{cov}\left[\tilde{u}^{\prime} \cdot \mathrm{d} \tilde{v}_{t} / \mathrm{d} l_{t}\right]$, which is negative, will increase. For both reasons, therefore, the right-hand side of eq. (5) will decline in a recession. The right-hand side of eq. (5) evaluated at a firm's existing level of employment represents the value of the wage contract that the firm will offer when it first begins expanding its labor force.

As firms accumulate equity over time, the right-hand side of eq. (5) will rise and

$$
\frac{\mathrm{d} y_{t+1}}{\mathrm{~d} l_{t+1}}=\sum_{i=0}^{\infty} w_{t+1+i} \delta_{i}+h_{t+1}>\frac{\mathrm{d} y_{t}}{\mathrm{~d} l_{t}}=\sum_{i=0}^{\infty} w_{t+i} \delta_{i}+h_{t} .
$$

If this gap is sufficiently large (because in the depths of a recession firms are sufficiently risk averse) so that, ignoring end effects (i.e., assuming workers are long lived relative to the length of a typical recession)

$$
\frac{\mathrm{d} y_{t+1}}{\mathrm{~d} l_{t+1}}>\left(1+r_{t}\right) \frac{\mathrm{d} y_{t}}{\mathrm{~d} l_{t}}
$$

where $r_{t}$ is an appropriate real interest rate for workers, then it is rational for workers to delay taking a long-term job until economic conditions improve. There are, in effect, no offers that firms would be willing to make in the depths of a recession that workers would be willing to accept.

The resulting 'unemployment' is involuntary in the sense that, absent informational imperfections, there is a Pareto improving bargain that could be struck between workers and firms. It consists, as in the lay-off case discussed above, of workers agreeing to accept contingent equity-like wage offers and absorb a greater share of the risks associated with higher output. But since the firms likely to offer these contracts (e.g., Eastern Airlines) are just the firms from whom workers do not want to accept them, such arrangements are difficult to make. ${ }^{20}$

\footnotetext{
${ }^{20}$ Two final remarks ought to be made about this kind of unemployment. First, in contrast to many models of cyclical unemployment, it arises precisely because workers recognize that they are in a recession, not because they are unable to distinguish between local and economy wide conditions. Second, the reason workers do not accept jobs and quit for new ones when conditions improve must depend on the informational cost (stigma) attached to such behavior discussed above on p. 000 . If this were not the case, then such behavior would itself deter hiring by firms since $\delta_{i}$ would now be small, reducing $\mathrm{d} \tilde{v}_{t} / \mathrm{d} l_{t}$ and wages but not $h_{t}$.
} 


\section{Efficiency wage models}

The models we have discussed explain fluctuations in the demand curve for labor. They also explain why even with perfectly flexible wages, there may be lay-offs: at the wages which firms would be willing to keep their employees, the employees are not willing to work; and though firms would be willing to promise to pay workers in the future for current work, such promises are not credible, given the informational imperfections.

During the past ten years, a different strand of literature has focused on a different set of limitations on information and on contracting in the labor market as an explanation of wage rigidity and unemployment. This literature argues that for a variety of reasons (selection, incentive, morale, turnover) net productivity increases with wages, sufficiently so that it may not pay firms to lower their wage, even in the face of an excess supply of labor. ${ }^{21}$ These efficiency wage theories have been used to explain the existence of competitive market equilibria with unemployment. Some versions of the theory explain why wages may not change at all, in the face of a change in the demand for labor; ${ }^{22}$ while in other versions ${ }^{23}$ the real wage falls somewhat, but not enough to absorb the full impact of the variability in the demand for labor. Thus, in these models, the variability in the demand for labor arising from the capital market imperfections discussed in previous sections of this paper gives rise to variability in employment: the two theories are thus complementary. ${ }^{24}$

Capital market imperfections interact with efficiency wage theory in two other ways. First, many of the efficiency wage arguments would be mitigated if workers had sufficient capital to post bonds, ensuring their performance; but capital market imperfections mean that unless they have inherited or saved sufficient capital, they cannot post an adequate bond. Indeed, in many instances the employment relationship itself arises from differential ownership of or access to capital. ${ }^{23}$

Secondly, firms' responses to changes in environment are affected by their attitudes towards risk; and the kinds of capital market imperfections on which we focused in previous sections induce risk averse behavior on the

\footnotetext{
${ }^{21}$ See Yellen (1984) or Stiglitz (1987) for a survey of these models.

${ }^{22}$ See Stiglitz (1985).

${ }^{23}$ See Shapiro and Stiglitz (1984).

${ }^{24}$ Other versions of the efficiency wage theory give less clear cyclical predictions. Thus, in the selection version, if the reservation (self-employment) wage falls in a recession, the primary sector wage may fall more or less proportionately.

Also, there has been some concern about the consistency of observed patterns of cyclical movements in productivity and wages with the effort-efficiency wage model. The threat of unemployment should presumably induce retained workers to work even harder in recessionary periods, yet productivity typically declines. As we have argued, however, in the primary sector workers have long-term relationships, and the incentive to work is provided by the long-term relationships, and the value of this is enhanced by some wage/employment smoothing.

${ }^{25}$ That is, self-employment obviates many of the sources of the efficiency wage problem.
} 
part of many firms. Thus, consider a disturbance to the economy; and assume that firms believe that, as a result of efficiency wage considerations, productivity depends on relative wages. There is still some uncertainty about the effect of the disturbance on their workers' productivity, even were they to keep their relative wage fixed; but this uncertainty increases if they change the relative wage. They may helieve that an increase (or decrease) in relative wages will increase profitability, but the increased uncertainty associated with such an action, combined with their risk aversion, induces them to keep wages fixed, thus precluding the kinds of responses which would facilitate the adjustment of the economy to the disturbance.

Efficiency wage theory has been particularly successful in explaining the pattern and form of unemployment, in explaining why there should bc differential unemployment rates among different groups, in explaining why changes in the demand for labor should have differential effects on different groups, and in explaining why a reduction in the demand for labor should take the form of lay-offs rather than work-sharing. It has not been able to explain why there should be fluctuations in the demand for labor (given that technology and capital stock seem to vary little in the short run). Our theory of capital market imperfections provides the missing link. For their part, efficiency wage theories are capable of explaining unemployment in secondary sectors of the economy and the existence of long-lived non-cyclical queues for primary sector jobs. Thus, they complete the full range of explanations of the various types of unemployment outlined in the introduction to this paper.

\section{References}

Akerlof, G., 1970, The market for lemons: Qualitative uncertainty and the market mechanism, Quarterly Journal of Economics 84, 288-300.

Arrow, K.J., 1970, Essays in the theory of risk bearing (North-Holland, London).

Asquith, P and D.W. Mullins, 1983, Equity issues and stock price dilution, Unpublished paper (Harvard Business School, Cambridge, MA).

Baily, M.N., 1977, On the theory of lay-offs and unemployment, Econometrica 45, 1043-1061.

Barrow, R. and H. Grossman, 1976, Money, employment and inflation (Cambridge University Press, Cambridge).

Greenwald, B., 1979, Adverse selection in the labor market (Garland Press, New York).

Greenwald, B and J.E. Stiglitz, 1986, Information, finance constraints and business fluctuations, Unpublished paper (Bell Communications Research, Morristown, NJ).

Greenwald, B., J.E. Stiglitz and A. Weiss, 1984, Informational imperfections and macroeconomic fluctuations, American Economic Review, Papers and Proceedings 74, 194-199.

Grossman, S.J., O.D. Ilart and E.S. Maskin, 1983, Unemployment with observable aggregate shocks, Journal of Political Economy 91, 907-928.

Jaffee, D. and T. Russell, 1976, Imperfect information and credit rationing, Quarterly Journal of Economics 90, 651-666.

Leland, H.E. and D.H. Pyle, 1977, Informational asymmetries, financial structure and financial intermediation, Journal of Finance 32, 371-387.

Malinvaud, E., 1977, The theory of unemployment reconsidered (Blackwell, Oxford).

Myers, S.C. and N.S. Majluf, 1984, Corporate financing and investment decisions when firms have information that investors do not, Journal of Financial Economics 11, 187-221. 
Ross, S.A., 1977, The determination of finance structure: The incentive signalling approach, Bell Journal of Economics 8, 23 40.

Rothschild, M. and J.E. Stiglitz, 1976, Equilibrium in competitive insurance markets: An essay on the economics of imperfect information, Quarterly Journal of Economics 90, 629-650.

Salop, S., 1979, A model of the natural rate of unemployment, American Economic Review 69, $117-125$.

Shapiro, C. and J.E. Stiglitz, 1984, Equilibrium unemployment as a worker discipline device, American Economic Review 74, 433-444.

Solow, R, and J.E. Stiglitz, 1986, Output, employment and wages in the short run, Quarterly Journal of Economics 82, 537-560.

Stiglitz, J.E., 1974, Wage determination and unemployment in LDC's: The labor turnover model, Quarterly Journal of Economics 88, 194-227.

Stiglitz, J.E., 1976, The efficiency wage hypothesis, surplus labour, and the distribution of income in LDC's, Oxford Economic Papers 28, 185-207.

Stiglitz, J.E., 1985, Equilibrium wage distributions, Economic Journal 95, 595-618.

Stiglitz, J.E., 1987, The causes and consequences of the dependence of quality on price, Journal of Economic Literature, forthcoming.

Stiglitz, J.E. and A.M. Weiss, 1981, Credit rationing in markets with imperfect information, American Economic Review 71, 393-410.

Taggart, R.A., 1983, Secular patterns in financing U.S. corporations, Unpublished paper (Harvard University, Cambridge, MA).

Wilson, C.A., 1977, A model of insurance markets with incomplete information, Journal of Economic Theory 14, 167-207.

Yellen, J., 1984, Efficiency wage models of unemployment, American Economic Review, Papers and Proceedings 74, 200-205. 